\title{
Pamięć zobowiązana. Rzecz o książce Anety Prymaki-Oniszk Bieżeństwo 1915. Zapomniani uchodźcy
}

\author{
Obliged memory. \\ About the book Exile 1915. Forgotten refugees by Aneta \\ Prymaka-Oniszk
}

\author{
Dorota Jewdokimow
Uniwersytet im Adama Mickiewicza w Poznaniu
}

\begin{abstract}
The text is a description and analysis of the Aneta Prymaka-Oniszk's book in regard to contemporary historiographic reflection. The main issue of the article which was taken into account is the ethical aspect of memory. Memory in this regard is directly connected with obligation of those people, whom stories were expressed and listened to. Prymaka-Oniszk recalls experiences of peasants in exile to the East from Warzone in 1915. The author allows refugees, being outside the discussion on the past, to take a floor and in this way she carries out main frameworks of historical anthropology, which is a specific sort of historical writing.
\end{abstract}

Key words: memory, postmemory, obligation, historical anthropology, refugee

Streszczenie: Tekst jest omówieniem treści książki autorstwa Anety Prymaki-Oniszk w kontekście współczesnej refleksji historiograficznej. Podstawowym, branym tu pod uwagę problemem pozostaje kwestia pamięci w jej etycznym ujęciu. Pamięć w takim jej rozumieniu łączy się bezpośrednio z kategorią zobowiązania odnoszącą się do tych, których opowieść nie została wypowiedziana i wysłuchana. Prymaka-Oniszk przywraca pamięć doświadczenia chłopów uczestniczących w ucieczce na Wschód z terenów objętych działaniami wojennymi w roku 1915. Oddając głos tym, którzy pozostawali dotychczas na marginesie dominującej narracji o minionych wydarzeniach, autorka książki realizuje główne założenia antropologii historycznej, będącej szczególnym rodzajem pisarstwa historycznego.

Słowa kluczowe: pamięć, postpamięć, zobowiązanie, antropologia historyczna, uchodźca

„Pamiętam niewiele. Prawie nic” (Prymaka-Oniszk 2016, 9). Takim stwierdzeniem otwiera swą książkę Aneta Prymaka-Oniszk, tym sposobem punktem wyjścia i zasadniczym jej tematem czyniąc zapomnienie obecne już w tytule pracy: Bieżeństwo 1915. Zapomniani uchodźcy, którego pierwsza część przywołuje określone zdarzenie historyczne, druga natomiast 
konkretnych uczestników owego zdarzenia. Bieżeństwo w opisie autorki przestaje być jedynie faktem, a staje się losem, jego trwanie nie ogranicza się do określonego momentu historycznego, a rozciąga się na przestrzeń życia kolejnych pokoleń potomków uczestników wędrówki na wschód z roku 1915, określając ich tożsamość i biografię, w tym również tożsamość i biografię samej autorki książki. Autorka uświadamiając sobie znikanie śladów pamięci, destrukcyjną moc zapominania, podejmuje pracę żmudnej rekonstrukcji zdarzeń, myśli, uczuć, przywracania pamięci zarówno tej indywidualnej, jak i zbiorowej, pamięci służącej budowaniu tożsamości jednostki i wspólnoty, kształtującej wrażliwość.

Lista źródeł, z jakich korzysta Aneta Prymaka-Oniszk w swej pracy restytucji pamięci, jest imponująca i świadczy o niezwykle drobiazgowo przeprowadzonej kwerendzie oraz doskonałym przygotowaniu merytorycznym. Autorka odnajduje i porządkuje dotychczas rozproszone materiały dokumentujące przebieg wydarzeń 1915 roku oraz kilku kolejnych lat ukazujących następstwa decyzji podjętych w kluczowym roku wypadków wojennych. Odnosi się do licznych opracowań kreślących szerszy kontekst historyczno-kulturowy bieżeństwa. Same materiały źródłowe dzielą się na dwie zasadnicze grupy: współczesne i archiwalne. Do pierwszej należą zbiory wspomnień, indywidualne relacje publikowane na łamach prasy oraz rękopisy zawierające opis minionych zdarzeń, a także wspomnienia bieżeńców oraz ich potomków zebrane i spisane już w latach 90. (Bieżanstwa 1915 hoda, 2000), jak również rejestrowane przez samą autorkę w latach 2012-2015. Wśród źródeł archiwalnych odnajdujemy natomiast bezpośrednie relacje świadków i uczestników bieżeństwa drukowane w gazetach i czasopismach bądź w formie osobnych publikacji. Pośród nich istotną rolę odgrywają pamiętniki autorstwa aktorów wypadków I wojny światowej (m. in. pamiętnik Pawlika „gospodarza na 10 hektarach, najpierw rolnika, potem ogrodnika w pow. bielskim”, „psalmisty-bieżeńca W.I. Paszczuka”, wspomnienia Fiedota Kudryńskiego wydane w roku 1917 w Piotrogrodzie pod tytułem Ludskije wołny. Bieżency). Autorka przytacza duże fragmenty relacji spisywanych na gorąco, tym samym oddając niejako głos głównym bohaterom swej książki. Prymaka-Oniszk wyraźnie różnicuje źródła współczesne i źródła archiwalne, jest w pełni świadoma ich zasadniczej odmienności: relacje pisane na gorąco odznaczają się między innymi zdecydowanie wyższym poziomem emocji, które wydają się wygasać wraz z upływem czasu: „W powtarzanych dziś wspomnieniach nie ma jednak tej złości. Nie mówi się o wściekłości na wojskowych, na cara, na urzędników. Dopiero w spisywanych na gorąco relacjach widać temperaturę ówczesnych nastrojów" (Prymaka-Oniszk 2016, 125). Bezpośrednie relacje są bardziej szczegółowe, podczas gdy w późniejszych miejsce drobiazgowości zajmuje pewna schematyczność, wraz z czasem zacierają się emocje i detale.

Czym jest tytułowe bieżeństwo w jego warstwie zdarzeniowej? Podczas I wojny światowej w roku 1915, po przełamaniu przez Niemców i Austriaków 
linii frontu w Karpatach, miał miejsce odwrót wojsk rosyjskich. Towarzyszyła temu masowa ewakuacja ludności cywilnej. Jako pierwsi w głąb imperium wysłani zostali urzędnicy. Z nimi odjeżdżały tony dokumentów, pakowane w pośpiechu biblioteki, dzieła sztuki, całe fabryki wraz z personelem i pełnym wyposażeniem. Jako ostatni wyjechali najubożsi mieszkańcy. „Gdy front jest już blisko, chłopi - dobrowolnie lub pod przymusem - pośpiesznie pakują dobytek i w rzędach furmanek suną na wschód. (...) Dotychczasowy świat obraca się w ruinę. Prości ludzie tracą wszystko. To, co mają, i to, kim są" (Prymaka-Oniszk 2016, 12). Według danych statystycznych odnalezionych przez autorkę bieżeństwo dotknęło trzy i pół miliona osób, inne źródła wskazują nawet na liczbę pięciu milionów. Na przymusową tułaczkę skazani zostali mieszkańcy guberni grodzieńskiej, w której skład w roku 1915 wchodziła współczesna Białostocczyzna, wsi wschodniej Chełmszczyzny oraz ziem ówczesnego Królestwa Polskiego: guberni łomżyńskiej, warszawskiej, suwalskiej. Swe domy opuszczali w głównej mierze prawosławni, poszukujący wsparcia u współwyznawców ze wschodu, ale wśród ówczesnych uchodźców znaleźli się również katoliccy Polacy, Litwini, Tatarzy, Żydzi i Niemcy. Rozkaz wysiedlania chłopów wydany zostaje przez dowódców armii rosyjskiej w obawie przed zasileniem przez nich sił wroga. W ten sposób realizowana jest „taktyka spalonej ziemi”, która w przeszłości pozwoliła Rosji odeprzeć atak Napoleona. Zgodnie z jej założeniami podążający za wycofującym się wojskiem rosyjskim wrogowie mają zastać „spaloną ziemię": palone są wcześniej opustoszałe miasta i wsie, niszczone kościoły i mosty, płoną pola dojrzewającego zboża. Podejmując decyzję o wysiedleniu milionów ludzi, nie przewidziano dalekosiężnych konsekwencji tego aktu. Imperium rosyjskie, pozostające wówczas w kryzysie, nie było przygotowane na przyjęcie rzeszy ludzi napływających z zachodu, pozostawiło więc ich w długiej tułaczce bez jakiejkolwiek pomocy. Bieżeńców wspierają organizacje pomocowe, które wkrótce okażą się bezradne wobec ogromu potrzeb ludzi pozbawionych dorobku całego życia. Za statystykami, datami, liczbami odnoszącymi się do wędrówki na wschód z roku 1915 kryją się realne losy, dramaty jednostek i to pamięć o nich najbardziej interesuje Anetę Prymakę-Oniszk. Aktualizowane są tragiczne losy najsłabszych spośród nich, stojących najniżej w drabinie społecznej: chłopów, a przede wszystkim matek chłopek i ich dzieci.

Korzystając ze wszystkich dostępnych źródeł, Prymaka-Oniszk odtwarza warstwę zdarzeniową branego przez siebie pod uwagę momentu historycznego, jak również myśli, emocje, motywacje towarzyszące bezpośrednim ich świadkom i uczestnikom. Przy tym to treść świadomości bieżeńców stanowi główny przedmiot zainteresowania autorki, jej głównym celem jest rekonstrukcja podmiotowej realności, odtworzenie obrazu świata ściśle określonej grupy ludzi, którzy znaleźli się w sytuacji ekstremalnej. Tą braną pod uwagę grupą pozostają chłopi, których głos był często pomijany i marginalizowany, pozostawał drugorzędny wobec dominującej narracji 
piśmiennej szlachty. Autorka wsłuchuje się w głosy tych, których opowieść przez lata spychana była na margines Historii. Podejmuje próbę przedarcia się przez dominującą narrację, dominujący schemat opowieści oparty na wypadkach wojennych. Precyzując swe intencje, autorka pisze:

Ale ja nie chcę słuchać wojskowych opowieści. Czytałam już o walkach, wiem, kto zwyciężył i jak bardzo było to skomplikowane. Wolałabym o pieleniu ogrodów u Kozaczek, o młóceniu przez całą zimę. O tym, co czują rodzice, patrząc na słabnące z głodu dzieci. Zresztą, jeśli już musimy rozmawiać o tych wojnach dziadka, wolałabym się dowiedzieć, gdzie chował się przed poborem do oddziałów białych (lub czerwonych). I jak z tymi, którzy po niego przychodzą, rozmawiała babcia. Przerywam więc, pytam kobietę o codzienne życie (Prymaka-Oniszk 2016, 206-207).

Aneta Prymaka-Oniszk opisując bieżeństwo, będzie koncentrowała się na sposobie przeżywania, doświadczania zdarzeń, indywidualizując je i konkretyzując.

Tak formułując swe cele, autorka w pełni realizuje postulaty właściwe przełomowi, jaki dokonał się w europejskiej historiografii w drugiej połowie $\mathrm{XX}$ wieku, a którego głównym dokonaniem było uwzględnienie podmiotowego aspektu w badaniach historycznych. Historia wówczas przestała być kolekcjonowaniem i porządkowaniem faktów, a jej głównym zadaniem stało się właśnie „odtworzenie obrazów świata właściwych dla różnych epok i tradycji kulturowych" (Guriewicz 1997, 13), co dało początek rozwojowi niezwykle płodnej poznawczo dziedzinie, jaką jest antropologia historyczna.

Antropologia historyczna w jej podstawowym ujęciu pozostaje przede wszystkim uprawianym przez współczesnych historyków nurtem pisarstwa historycznego wykorzystującym w badaniu przeszłości inspiracje zaczerpnięte z obszaru antropologii. Pośród tych inspiracji Ewa Domańska wymienia między innymi charakterystyczne ujęcie przeszłości dokonywane „od dołu”, w skali mikro, z perspektywy „zwykłych ludzi”, skupienie na właściwych badaniom etnograficznym tematach, takich jak kultura wiejska, życie codzienne, obyczaje. Kolejną inspiracją będzie wykorzystanie

źródeł historycznych, które pozwalają przemówić zwykłym ludziom (nieznanym czy/i marginalizowanym przez wielką Historię) oraz umożliwiają rekonstrukcję losów indywidualnych postaci i grup społecznych i napisanie ich kulturowych biografii (m.in. pamiętniki, listy, zeznania, kazania, a także lokalne opowieści, obrazy, muzyka, przedmioty kultury materialnej, fotografie itd.) (Domańska 2014, 18).

Antropologia historyczna korzysta również z metod badań terenowych. Wszystkie spośród wymienionych inspiracji właściwe są pisarstwu uprawianemu przez Anetę Prymakę-Oniszk, co pozwala je lokować w obszarze antropologii historycznej właśnie. Jednakże o ile antropologia historyczna koncentruje się przede wszystkim na zwykłych ludziach w ich codzienności, to opisywani przez autorkę „zwykli ludzie” znajdują się w niezwykłej dla siebie sytuacji. Chłopi zachodnich rubieży imperium rosyjskiego i wschodniego pasa przygranicznego Królestwa Polskiego zastali przedstawieni 
w momencie, gdy ich codzienna rzeczywistość uległa całkowitemu rozkładowi, wszystko, co znali, rozpadło się:

Staliśmy się nie ludźmi, ale liśćmi. Wiatr nas goni, gdzie chce« - mówi zrozpaczona bieżenka. Nie wiem, skąd pochodzi. Czy jest Rusinką, Polką czy Łotyszką? Zresztą to nieważne. Los wszystkich jadących jest równie tragiczny. Stracili wpływ na swoje życie. Bieżeństwo to historia stopniowej utraty. Zaczyna się zaraz po wybuchu wojny - utratą męża, którego zabrali na front. Potem armia rekwiruje zwierzęta. W końcu nadchodzi wyjazd. Traci się dom, ziemię, cały świat. Korzenie i tożsamość. Odwieczne rytuały, sposób życia, niezmienny od stuleci (Prymaka-Oniszk 2016, 85).

W tych warunkach dotychczasowy obraz świata podlega dezintegracji, dotychczas obowiązujące normy zostają zawieszone.

Uwzględniając podmiotowy aspekt w badaniach historycznych, historiografia drugiej połowy XX wieku zwróciła uwagę na szczególne usytuowanie badacza względem przedmiotu swych badań. Przedmiotem badania historyka pozostają ludzie, a zatem w badaniu takim każdorazowo dochodzi do spotkania odrębnych myślących i czujących bytów, konstytuuje się przestrzeń dialogu, pomiędzy subiektem a obiektem tworzy się określona relacja. Dialog ten „wprowadza w badanie historyczne system wartości historyka" (Guriewicz 1993, 15). Badacz jest każdorazowo zanurzony w określonych warunkach historyczno-kulturowych, posługuje się właściwymi dla tych warunków kategoriami opisu rzeczywistości, stosując je jednocześnie w odniesieniu do rzeczywistości minionej. A zatem historyk nigdy nie tworzy wiernego obrazu przeszłości, zawsze pewnym zakresie ową przeszłość konstruuje. Dodatkowo nigdy nie ma bezpośredniego dostępu do przeszłości, odtwarzając ją, posługuje się źródłami, które stanowią produkt myśli innego człowieka, a zatem stanowią już pewnego rodzaju interpretację rzeczywistości minionej.

Dostrzeżenie istotnego wpływu osoby przedstawiającej pewien odcinek rzeczywistości na ostateczny kształt owego przedstawienia, świadomość zapośredniczonego dostępu do rzeczywistości określa się w humanistyce jako zwrot narratywistyczny. Narratywiści odrzucą możliwość wiernego odtworzenia w tekście rzeczywistości pozatekstowej, podważą samą koncepcję literatury faktu, „ponieważ zakłada ona istnienie prawdy zewnętrznej oraz tekstu, który jest w stanie ją odtwarzać” (Zajas 2011, 14). Choć narratywizm od momentu swego pojawienia się był wielokrotnie krytykowany, przede wszystkim ze względu na zawarte w nim ryzyko skrajnego relatywizowania rzeczywistości, wpłynął znacząco na sposób różnicowania gatunków literackich i pozaliterackich. Konsekwencją tego będzie między innymi zamazanie granicy między tekstami niefikcjonalnymi, referencjalnymi a tekstami fikcjonalno-artystycznymi. „Teksty o wyraźnie zarysowanych granicach genologicznych ustępują miejsca gatunkom hybrydycznym, transgresyjnym" (Zajas 2011, 14). Następuje dość ryzykowny zwrot od genologii ku antropologii, przejawiający się w zmianie kształtu samej prozy niefikcjonalnej, która podlega procesowi subiektywizacji. Schematy 
i porządki gatunkowe traktowane są jako „podręczne narzędzie do wyrażania jednostkowego punktu widzenia" (Grochowski 2005, 654). Dostrzega się „nasycenie literatury faktu spersonalizowaną ekspresją, rozluźnianie rygorów metodologicznych i faktograficznych, porzucanie klasycznych form reportażu" (Zajas 2011, 15). Literatura faktu zmienia swój dotychczasowy kształt, podlega stopniowej beletryzacji, rezygnuje z programowego niegdyś dążenia do „obiektywizmu, przezroczystości języka i wierności autentycznym wydarzeniom" (Zajas 2011, 16). Dążenie to wynika z oczywistego procesu filtrowania rzeczywistości przez indywidualne doświadczenie, staje się jednak problematyczne w momencie łamania przez autorów „paktu referencjalnego”, wyznaczającego granice gatunku. Pakt ten stanowi niepisaną umowę między piszącym a czytelnikiem, „opiera się na pojęciu prawdomówności (świadectwa)" (Lejeune 2001, 285), na obietnicy mówienia prawdy.

Zmiany dokonujące się $\mathrm{w}$ ramach pisarstwa historycznego oraz przeobrażenia dotyczące gatunków literatury niefikcjonalnej prowadzą do zamazania granic między historią a literaturą. Pisarstwo Anety Prymaki-Oniszk w swym dążeniu do obiektywizmu i ukazania różnorodnych perspektyw widzenia rzeczywistości minionej lokuje się na pograniczu antropologii historycznej i literatury faktu. O usytuowaniu książki na pograniczu literatury i historii świadczą choćby nominacje i nagrody przyznawane autorce. Aneta Prymaka-Oniszk otrzymała Nagrodę Literacką Prezydenta Miasta Białegostoku im. Wiesława Kazaneckiego, była nominowana do Nagrody Literackiej m. st. Warszawy w kategorii „proza”, znalazła się również wśród finalistów Nagrody Kapuścińskiego za Reportaż Literacki. Pośród wielu wyróżnień istotne miejsce zajmuje także nominacja do Nagrody Historycznej im. Kazimierza Moczarskiego za najlepszą książkę mówiącą o historii polskiej po roku 1918.

Rozwinięcie pisarstwa historycznego w postaci antropologii historycznej przesuwa je w kierunku literatury niefikcjonalnej, literatury faktu, co wydaje się czynić Prymaka-Oniszk. Świadomość niemożności utrzymania neutralnej postawy badacza wobec rzeczywistości, diagnozowana w historiografii drugiej połowy XX wieku, zastąpiona zostaje w pisarstwie autorki Bieżeństwa 1915 ekspozycją podmiotowości badacza, podkreśleniem indywidualnej perspektywy opisu rzeczywistości. W wielu fragmentach swej książki autorka wskazuje na proces przetwarzania doświadczenia bieżeńców przez własną wrażliwość, wielokrotnie porzuca rygory metody badań terenowych, jaką jest obserwacja uczestnicząca łącząca perspektywę wewnętrzną i zewnętrzną. Jej główną metodą pracy, poznania rzeczywistości staje się metoda empatii, wczucia: „Staram się wczuć w skórę orchowskich chłopów sprzed stu lat” (Prymaka-Oniszk 2016, 44), „Próbuję się wczuć w docierających gdzieś na Syberię czy nad Don ludzi" (Prymaka-Oniszk 2016, 162). Autorka wciąż uobecnia swą podmiotowość, jej wyobraźnia i wrażliwość stają się filtrem, przez który obserwujemy opisywaną przez 
nią realność. Zabieg uobecnienia w tekście uzasadniony jest jej osobistym uwikłaniem w historię bieżeństwa; będąc potomkinią bieżeńców, staje się bezpośrednią spadkobierczynią ich pamięci, co czyni ją niejako równoprawną bohaterką książki, udziela sobie głosu, równoważąc go następnie głosami samych bieżeńców, których obszerne fragmenty wypowiedzi przytacza. W tworzonej strukturze polifonii, udzielając głosu samej sobie, staje się jednym z bohaterów pisanej przez siebie książki.

„Znikanie”, zacieranie śladów zdarzeń i ludzi, zapominanie uświadomiono sobie, według Autorki, w latach 80. i 90. XX wieku, gdy zaczęli umierać bezpośredni świadkowie, a opowieści zawierały coraz mniej szczegółów. Świadomość ta dotknęła pierwsze pokolenie „miastowych” potomków bieżeńców:

W Białymstoku, Bielsku Podlaskim, Hajnówce, Sokółce dorosło pierwsze pokolenie miastowych potomków bieżeńców. Jeszcze mocno związani ze wsią; urlop spędzają u krewnych przy żniwach czy sianokosach. Niektórzy - nauczyciele szkolni i akademiccy, dziennikarze, literaci, artyści, naukowcy - pracują na rzecz swojej kultury, teraz nazywanej kulturą mniejszości białoruskiej, ukraińskiej czy prawosławnej. Dostrzegają, jak ważne jest dla niej bieżeństwo. I że pamięć wkrótce odejdzie (Prymaka-Oniszk 2016, 52).

Świadomość ulotności pamięci zdarzeń, a zarazem ich znaczenia dla własnej tożsamości zrodziła potrzebę utrwalenia śladów, spisania opowieści, czego rezultatem była wydana w roku $2000 \mathrm{w}$ języku białoruskim książka Bieżanstwa 1915 hoda, będąca dla Autorki bogatym źródłem wiedzy o doświadczeniu uchodźstwa jej przodków. Książka ta, co znaczące, nazywana jest „obrazem współczesnej pamięci o bieżeństwie”, jest to pamięć przetworzona, zawierająca już pewien powtarzalny schemat. Fakt przetworzenia rzeczywistości dawnego doświadczenia widoczny jest wyraźnie w przywołanych opowieściach świadków, którzy podczas zdarzeń byli małymi dziećmi, natomiast opowiadając o nich, rozpoznają emocje i motywacje dorosłych, swoich rodziców, dziadków w taki sposób, w jaki czyniłyby to osoby dojrzałe. A zatem ich opowieści stanowiły aktualną interpretację doświadczenia, nie natomiast samo doświadczenie, w tym sensie pozostają współczesnym obrazem przeszłości, ujawniają one równocześnie mechanizm pracy „postpamięci”, do którego powrócimy w finale niniejszego tekstu.

Autorka doskonale zdaje sobie sprawę z deformacji pamięci wynikającej z określonej interpretacji faktów. Istotnym problemem książki, choć nie wyrażanym bezpośrednio, to jednak powracającym wciąż w komentarzach, pozostaje problem relacji między zdarzeniem a narracją. Inaczej bieżące wydarzenia interpretowali chłopi, inaczej panowie:

Ważna dla zrozumienia bieżeństwa i późniejszych opowieści o nim jest różnica klasowa. Narracja szlachecka i narracja chłopska. (...) Z licznych zachowanych relacji wynika, że w drogę udaje się zdecydowana większość szlachty i ziemian. Nie będą oni jednak określać się jako bieżeńcy - uciekinierzy. W listach, pamiętnikach, wspomnieniach mówią o sobie raczej: wygnańcy, którzy jadą pod przymusem niczym 
na zsyłkę. Swój los wpisują w narrację o prześladowaniach ze strony rosyjskiego zaborcy. Za to o chłopach, zwłaszcza białoruskich czy ukraińskich, chętnie piszą jako o dobrowolnych uciekinierach (Prymaka-Oniszk 2016, 61).

Kolejnym elementem różnicującym sposób opowiadania o wydarzeniach roku 1915 jest przynależność etniczna konstytuowana w odniesieniu do reprezentowanego wyznania; inna jest perspektywa polska, katolicka, inna zaś „ruska”, prawosławna. „Ruscy” i Polacy, chłopi i szlachta w sposób odmienny ujmowali, porządkowali i wyjaśniali otaczającą ich rzeczywistość. Autorka książki przywołuje wszystkie te dyskursy. Tym, co pozwala jej uniknąć relatywizmu wynikającego z koncentracji na samych tylko tekstach stanowiących rodzaj przetworzenia doświadczenia, jest odwołanie do realności samego doświadczenia, doświadczenia bólu fizycznego i psychicznego, doświadczenia utraty. Odwołanie to pozwala uniknąć pułapki tkwiącej w samym tekstualizmie i konstruktywizmie pojawiającym się w badaniach historycznych, przede wszystkim za sprawą koncepcji Haydena White'a, zgodnie z którymi „przeszłość nie istnieje niezależnie od jej przedstawienia”, zaś „rzeczywistość jest czystym, pozbawionym sensu strumieniem i to historycy wyposażają przeszłość w znaczenie” (Domańska 2005, 90-91), sens przeszłości nie jest czymś, co odkrywamy, a czymś, co konstruujemy ${ }^{1}$.

Nasycenia ideologiczne, pewna interpretacja zdarzeń zawiera się już w samym określeniu bieżeńcy, które to określenie de facto odnosi się do kogoś, kto z własnej woli opuszcza swą ziemię, pojęcie to w sposób jednoznaczny lokuje intencję do porzucenia ziemi po stronie samych uchodźców, zdejmując odpowiedzialność z ich otoczenia, w tym ze świadków dramatycznego marszu rzeszy ludzi napływających z zachodu.

Bieżenców-uchodźców z domu wygoniła wojna; to ona jest winna tej katastrofie. Inny popularny wówczas termin: „wysiedleńcy” (czyli przesiedleńcy, wygnańcy) nasuwa pytanie o sprawców. Bo kto i po co wysiedlał? Kto wyganiał? Przesiedlać można co najwyżej Niemców (Prymaka-Oniszk 2016, 105).

I to właśnie określenie „wysiedleńcy” zaczyna zastępować dotychczasowy termin „bieżeńcy”, tym samym wprowadzając nową interpretację zdarzeń. Zmiana ta, istotna na poziomie sporów ideologicznych, gdzie każdy obstaje po stronie swych racji, jest nieistotna $\mathrm{z}$ punktu widzenia tożsamości samych chłopów, uczestników wielkiej wędrówki na wschód. Aneta Prymaka-Oniszk pisze:

Używając terminu „bieżeństwo”, przejmujesz carską propagandę. Taki zarzut słyszę i ja, prowadząc stronę Bieżeństwo.pl. Tak mówią mi ludzie z Warszawy, Łomży lub Zambrowa. Oraz świadomi bieżeństwa Rosjanie (choć temat w Rosji w zasadzie

${ }^{1}$ Problem relatywizacji prawdy historycznej w historii skupionej na badaniach samej tylko reprezentacji pojawił się w roku 1989 w dyskusji między Haydenem Whitem a Carlo Ginzburgiem toczonej między innymi w odniesieniu do doświadczenia Holokaustu. Por. Friedländer Saul, 1992, Introduction, w: Probing the Limits of Representation: Nazism and the "final Solution", Friedländer S. (red.), Cambridge, s. 1-21. Konieczność odniesienia narracji do doświadczenia ustanawia natomiast Franklin R. Ankersmit, wychodząc poza horyzont dotychczasowych zainteresowań badawczych narratywistów. Por. Ankersmit Franklin R., 2004, Narracja, reprezentacja, doświadczenie. Studia z teorii historiografii, Domańska E. (red.), Kraków. 
nie istnieje). Potomkowie bieżeńców z Podlasia w większości nie rozumieją, w czym problem. Znają rodzinne opowieści, nie orientują się zbyt mocno w politycznych kulisach bieżeństwa, niuansach carskiej propagandy. Przez całe życie słyszeli właśnie o „bieżeństwie”. Ich dziadkowie byli bieżeńcami. Tak o sobie mówili. Dlaczego oni, potomkowie, mieliby nazywać ich inaczej? Też nie czuje sensu przemianowania bieżeństwa na wygnanie czy tułaczkę. Nie mam prawa odbierać bieżeńskiej tożsamości swoim przodkom ani jej przerabiać. Chcę ją zrozumieć i opisać (Prymaka-Oniszk 2016, 107).

Zaangażowanie w spory ideologiczne i rozważania wokół stosowanych określeń pozwalają abstrahować od samego doświadczenia bieżeństwa, izolować je i uznać za zewnętrzny przedmiot opisu. Aneta Prymaka-Oniszk przywraca owo doświadczenie, lokuje je wewnątrz samej siebie, wewnątrz potomków bieżeńców, współodczuwając, wychodzi poza jego ujęcia dyskursywne. Przywraca kontakt z doświadczeniem wewnętrznym, uruchamia mechanizm empatii, przez przypomnienie, aktualizację niepokoi i nie pozwala zamykać oczu (tak jak czynił to jeden ze świadków bieżeństwa, który w rozmowie przytaczanej przez Kudryńskiego mówił: „Wie pan, ja po prostu zamykam oczy, by niczego nie widzieć" (Prymaka-Oniszk 2016, 127)). Podstawowym wymiarem jej tekstu jest wymiar etyczny, stąd w kontekście treści książki pojawiają się określenia: uczciwość, odpowiedzialność, zobowiązanie. Książka przywołując doświadczenie bieżeństwa, uchodźstwa, ma szczególne znaczenie dla czasów współczesnych. Autorka unika w swym tekście jasnych i bezpośrednich nawiązań do współczesności, jednak podobieństwo pewnego mechanizmu społecznego ujawniającego się przede wszystkim na poziomie postaw wobec uchodźców nie może pozostać niedostrzeżone. Przy tym otrzymujemy opis całego wachlarza różnych reakcji i zachowań, często skrajnie różnych, pojawia się miłosierdzie, lęk, agresja, obojętność, każda z tych reakcji zdaje się być głęboko zakorzeniona w emocjach tych, którzy je przejawiają. Aneta Prymaka-Oniszk żadnej z tych reakcji nie poddaje ocenie, nie potępia i nie poucza. Pozostając bezstronną, każe czytelnikowi określić własną postawę wobec opisywanej rzeczywistości, przez co to na niego przesunięty zostaje ciężar odpowiedzialności za to, jaką postawę przyjmie wobec uchodźców - tych sprzed stu lat i tych współczesnych.

Zapomnienie, będące jednym z głównych tematów książki Prymaki-Oniszk, obok swego elementu destruktywnego, zawiera również element terapeutyczny, chroni jednostki i wspólnoty przed bólem i cierpieniem, a zatem jego funkcja nie zawsze jest jednoznacznie negatywna. Rozpoznanie różnych użyć zapomnienia, zarówno na płaszczyźnie doświadczenia indywidualnego, jak i zbiorowego odnajdujemy w hermeneutycznej pracy Paula Ricoeura. Ustanowione przez niego rozróżnienie może być stosowane i ma wartość wyjaśniającą w odniesieniu do mechanizmów zacierania pamięci, dostrzeganych i opisywanych przez Prymakę-Oniszk. Ricoeur, badając użycia i nadużycia zapomnienia, odwołuje się do wstępnie ustalonej typologii, 
opartej na dwóch regułach klasyfikacyjnych, spajających „to, co najgłębiej położone, z tym, co najbardziej jawne, najbardziej bierne z tym, co najbardziej aktywne" (Ricoeur 2006, 586). Typologia ta dokonuje rozpoznania trzech rodzajów zapomnienia związanych kolejno z pamięcią zablokowaną, pamięcią zmanipulowaną oraz pamięcią zobowiązaną. Każdy z wymienionych typów zapomnienia w swym przejawie indywidualnym, zgodnie z przekonaniem Ricoeura, wchodzi w skomplikowane relacje ze swymi formami zbiorowymi. Pierwszy rodzaj zapomnienia, związany z pamięcią zablokowaną, stanowi przedmiot badań psychoanalitycznych. Jego treścią pozostaje wyparte doświadczenie traumatyczne. Wyparta, czasowo niedostępna, treść, manifestując się w zamaskowanej formie symptomów, podlegałaby jednak, w ramach wspólnej pracy psychoanalityka i pacjenta, odczytaniu i przywróceniu. Zapomnienie, w tym jego ujęciu, ma charakter tymczasowy i odwracalny, jest mechanizmem chroniącym jednostkę przed treściami dla niej przykrymi. Poza obszarem pamięci zablokowanej, z jej funkcją ochronną, znajduje się zapomnienie i pamięć zmanipulowana, stanowiąca formę nadużycia. Jednak nadużycie poprzedza użycie wynikające z „nieuchronnie wybiórczego charakteru opowieści” (Ricoeur 2006, 590). Różne strategie narracyjne („zawsze można opowiadać inaczej - uwypuklając, przemieszczając znacząco akcenty, odmiennie przekomponowując protagonistów, a zarazem zarysy akcji" (Ricoeur 2006, 590)) umożliwiają ideologizację pamięci, o czym szczegółowo pisze sama Prymaka-Oniszk, prezentując różne narracje bieżeńców. Według Ricoeura:

Główne niebezpieczeństwo tkwi w manipulowaniu autoryzowaną, narzucaną, celebrowaną, upamiętnianą historią - historią oficjalną. Narracja jako środek staje się wówczas pułapką, gdyż wyższe moce przejmują jej kompozycję fabularną i narzucają kanoniczną narrację poprzez zastraszenie bądź uwiedzenie, strach lub pochlebstwo (Ricoeur 2006, 590-591).

Jednostki pozbawione zostają mocy snucia własnej opowieści, co dzieje się często przy ich współudziale, polegającym na zaniechaniu, unikaniu wiedzy, pragnieniu pogrążenia się w zapomnieniu, zgodzie na deficyt pamięci. Jedyną formą oporu wobec tego rodzaju zapomnienia jest, według Ricoeura, przekształcona dewiza oświeceniowa: „sapere aude! Wyrwij się spod kurateli! Zdobądź się na samodzielną opowieść!” (Ricoeur 2006, 591) Własna opowieść jest jedyną bronią przeciw nadużyciom pamięci, pozostając jednocześnie rodzajem zobowiązania. Aneta Prymaka-Oniszk podejmuje to zobowiązanie wobec siebie i wobec tych, których opowieść została zmarginalizowana, których indywidualny dramat pominięty. Jej gest przywrócenia pamięci stanowi po części indywidualną pracę terapeutyczną, pozwalającą określić istotny obszar własnej tożsamości, będąc jednocześnie gestem etycznym, wypełnieniem zobowiązania wobec innych.

Ujęcie pamięci jako zobowiązania, wyrażone przez Ricoeura w pracy opublikowanej w roku 2003, pojawiło się w refleksji francuskiej już w latach 
80., kiedy to pod wpływem wydarzeń związanych z rozpadem ZSSR i radykalnej zmiany dotychczasowego ładu światowej polityki, refleksja dotycząca kwestii pamięci stała się szczególnie istotna. Francis Fukuyama postawił wówczas tezę o „końcu historii”, który oznaczałby zwieńczenie procesu historycznego w postaci zwycięstwa systemu liberalnej demokracji. Francuski historyk Pierre Nora natomiast pisze w roku 1989 o pojawieniu się „nowego rodzaju historyków” oraz „nowej wrażliwości”. Według Pierra Nory milieux de memoire, czyli rzeczywiste środowiska pamięci, zostały zastąpione przez lieux de mémoire, miejsca pamięci. Zgodnie z formułowaną przez niego diagnozą nastąpił koniec społeczeństw, „które przez długi czas - dzięki kościołom lub szkołom, rodzinom lub państwu - gwarantowały transmisję i zachowanie zbiorowo pamiętanych wartości" (Nora 2009 , 4). Tożsamość wcześniej konstytuowała się w odniesieniu do pamięci zbiorowej, współcześnie natomiast zanik tradycyjnych form pamiętania zobowiązuje jednostkę do pamięci indywidualnej. Jak przekonuje Nora:

Atomizacja ogólnej pamięci w pamięć prywatną nadała obowiązkowi pamiętania moc wewnętrznej konieczności. Nakazuje ona każdemu pamiętać i chronić przywileje tożsamości; gdy pamięć nie jest już wszędzie, nie będzie jej nigdzie, jeśli ktoś nie weźmie odpowiedzialności za dochowanie jej przy pomocy indywidualnych środków. Im mniej doświadczamy pamięci zbiorowo, tym bardziej jednostki zmuszone są stać się jednostkami pamięci (Nora 2009, 8).

Pamięć wymaga zaangażowania, pozostaje rodzajem indywidualnego zobowiązania, w ujęciu Pierra Nory pamięć ujawnia swój etyczny wymiar.

Zgodnie z ustaleniami polskiej badaczki Anny Mach, „Lata osiemdziesiąte (...) stanowiły szczególny czas rozkwitu studiów nad pamięcią zarówno zbiorową, jak i jednostkową, a także jej powiązaniami z doświadczaniem traumatycznych wydarzeń" (Mach 2016, 79). Istotna w tym kontekście staje się przywołana przez autorkę Świadków świadectw koncepcja hauntologii - „widmowej ontologii” Jacques'a Derridy sformułowanej w ramach krytyki dyskutowanej wówczas kwestii „końca historii”. Koncepcja ta „zawiera w sobie nawiedzenie, prześladowanie, pojęcie nawoływania, przywoływania głosu oraz składania świadectw, przemawiania w imieniu umarłych i odbywania żałoby" (Mach 2016, 82). W interpretacji Anny Mach hauntologiczny „obowiązek pamięci” można odczytywać „w kontekście widmowej obecności nieopłakanych, nieodżałowanych należycie ofiar ludobójstw XX wieku" (Mach 2016, 82).

Przywołane za Anną Mach rozważania dotyczące kwestii „obowiązku pamięci” kreślą istotną ramę rozumienia treści prezentowanej tu książki Bieżeństwo 1915. Zgodnie z przytoczonymi wcześniej słowami Prymaki-Oniszk zainteresowanie bieżeństwem i pierwsze próby przywrócenia pamięci o nim pojawiły się w latach 80 . i 90., co czyni je zarówno konsekwencją, jak i dowodem określonej zmiany wrażliwości historycznej, o której pisał między innymi Pierre Nora. Praca Bieżeństwo 1915 stanowi niejako kontynuację i zwieńczenie podjętego wcześniej „zobowiązania”. W takim 
porządku interpretacyjnym możemy ją uznać za odpowiedź na wołanie „nieopłakanych ofiar”, a także włączyć w ramy dyskursu „postpamięci”. Termin „postpamięć” został użyty przez Marianne Hirch jako określenie pamięci odziedziczonej i odnosił się przede wszystkim do potomków ofiar Holokaustu. Termin ten może być jednak zastosowany również w stosunku do innych społeczności naznaczonych traumą. Problematyka postpamięci „ustanawia ponadpokoleniową przestrzeń pamięci”, zdefiniowaną przez „utożsamienie z ofiarami lub świadkami traumatycznych wydarzeń, jednocześnie zaś uwarunkowaną przez nieprzekraczalny dystans, który oddziela uczestników od tych urodzonych już po wydarzeniach" (Hirsch 2001, 11). Choć treść pamięci ofiar Szoa jest całkowicie odmienna od treści pamięci uczestników bieżeństwa, albowiem dotyczy odrębnych doświadczeń i zdarzeń, to mechanizm jej funkcjonowania wydaje się w dużym stopniu zbieżny, tym sposobem pojęcie postpamięci zachowuje swą moc wyjaśniającą również w obszarze interesującego autorkę Bieżeństwa 1915 doświadczenia przedstawicieli potomków uchodźców czasów I wojny światowej. Istotna dla problematyki postpamięci ekspozycja podmiotowości i identyfikacji jest właściwa dla pozycji przyjętej przez samą Anetę Prymakę-Oniszk wobec jej przodków. Wypełnia ona zadanie pokolenia postpamięci przejęcia roli świadka, podejmuje się zadania rozpoznania i przyswojenia wydarzeń, odzyskuje „dla międzypokoleniowej wspólnoty pamięci” opowieści bezpośrednich świadków wydarzeń, mając przewagę w postaci dystansu czasowego wobec minionego, konfrontuje się z traumatycznym doświadczeniem bieżeństwa. Cząstka „post” w terminie użytym przez Hirsch oznacza „opóźnienie” wynikające z oddziaływania traumy. Praca postpamięci jest konieczna, wiąże się z odzyskaniem „zerwanego przekazu” (Mach 2016, 86-87), nie jest jednak rozpamiętywaniem, a służy odbudowaniu komunikacji międzypokoleniowej. Opis mechanizmu postpamięci wiąże „pamięć zablokowaną” przodków z „pamięcią zobowiązaną” potomków. Przyszłe pokolenia urodzone już po obu wojnach światowych, wzmocnione dystansem czasowym i swym doświadczeniem mają obowiązek przyswojenia doświadczenia, które nie mogło być całkowicie przyswojone i przepracowane przez bezpośrednich uczestników wydarzeń traumatycznych. Zobowiązanie to, zobowiązanie pamięci wypełnia Aneta Prymaka-Oniszk.

\section{Bibliografia}

Ankersmit Franklin R., 2004, Narracja, reprezentacja, doświadczenie. Studia $z$ teorii historiografii, Domańska E. (red. i przeł.), Kraków.

Domańska Ewa, 2005, Mikrohistorie. Spotkania w międzyświatach, Poznań.

Domańska Ewa, 2014, Montaillou - ziemia obiecana błędów, w: Le Roy Ladurie Emmanuel, Montaillou. Wioska heretyków 1294-1324, Czerwonak, s. 5-23.

Friedländer Saul, 1992, Introduction, w: Probing the Limits of Representation: Nazism and the „final Solution”, Friedländer S. (red.), Cambridge, s. 1-21. 
Grochowski Grzegorz, 2005, Pytania o niefikcjonalna prozę dyskursywna, w: Polonistyka w przebudowie, Czermińska M. (red.), Kraków.

Guriewicz Aron, 1997, Historia i antropologia historyczna, Żyłko B. (przeł.), „Konteksty. Sztuka Ludowa”, nr 1-2, s. 13-20.

Guriewicz Aron, 1993, Istoriczeskij sintez i szkoła „Annałow”, Moskwa.

Hirsch Marianne, 2001, Surviving Images: Holocaust Photographs and the Work of Postmemory, "The Yale Journal of Criticism”, Vol. 14, No1.

Lejeune Philippe, 2001, Wariacje na temat pewnego paktu. O autobiografii, Grajewski W., Grabowski S., Labuda A., Lubas-Bartoszyńska R. (przeł.), Lubas-Bartoszyńska R. (red.), Kraków.

Mach Anna, 2016, Świadkowie Świadectw, Warszawa - Toruń.

Nora Pierre, 2009, Między pamięciq a historią: Les lieux de mémoire, „Tytuł roboczy: Archiwum", nr 2, s. 4-12.

Prymaka-Oniszk Aneta, 2016, Bieżeństwo 1915. Zapomniani uchodźcy, Wołowiec.

Ricoeur Paul, 2006, Pamięć, historia, zapomnienie, Margański J. (przeł.), Kraków.

Zajas Paweł, 2011, Jak świat prawdziwy stał się bajka. O literaturze niefikcjonalnej, Poznań.

\section{O Autorce:}

Dorota Jewdokimow - adiunkt w Instytucie Kulturoznawstwa UAM w Poznaniu. Autorka książek: Człowiek przemieniony. Fiodor M.Dostojewski wobec tradycji Kościoła Wschodniego (Poznań 2009), Na stycznej. Idea zjednoczenia Kościołów w rosyjskiej myśli filozoficzno-religijnej i społecznej (Poznań 2017) oraz wraz z Karoliną Kizińską Cultural Theory and History: Sign and Context (Poznań 2014). W centrum jej zainteresowań naukowych sytuuje się problematyka semiotyki historii oraz zagadnienia z zakresu rosyjskiej refleksji filozoficzno-religijnej i społecznej. 
